Diabetologia 8, 267-273 (1972)

(C) by Springer-Verlag 1972

\title{
Increased Lipid Synthesis by Liver Slice in a Superfusion System Following Raised Glucose or Insulin Concentration
}

\author{
B. R. Tulloch, K. Dyal and T. Russel Fraser \\ Endocrine Unit, Department of Medicine, Royal Postgraduate Medical School, London W. 12 \\ Received: February 23, 1972, accepted: May 2, 1972
}

\begin{abstract}
Summary. The synthesis of lipid from ${ }^{14} \mathrm{C}$-glucose and ${ }^{3} \mathrm{H}$-alanine was measured from rat liver slices using a micro-superfusion technique that allows continuous monitoring of the perifusate output. Increase in substrate glucose results in prompt elevation of fatty acid synthesis. Insulin addition also produced an increased ${ }^{14} \mathrm{C}$ incorporation into lipid. The effects were independent. Both these factors may be active in the hypertriglyceridaemia of high carbohydrate intake or diabetes.

Augmentation de la synthèse des lipides par des coupes de foie dans un système de superfusion après élévation de la concentration de glucose ou d'insuline

Résumé. La synthèse des lipides à partir du ${ }^{14} \mathrm{C}$-glucose et de la ${ }^{3} \mathrm{H}$-alanine fut mesurée dans des tranches de foie de rat, en utilisant une technique de microsuperfusion qui permettait l'enregistrement continu du débit du périfusat. L'addition de glucose amena une hausse immédiate de la synthèse d'acide gras. L'addition d'insuline provoqua de même une augmentation de l'incorporation de ${ }^{14} \mathrm{C}$ dans les lipides. Les effets étaient indépendants. Ces
\end{abstract}

deux facteurs pourraient être actifs dans l'hypertriglycéridémie après l'absorption importante d'hydrates de carbone ou dans l'état diabétique.

Erhöhte Lipidsynthese von Leberschnitten in einem Superfusionssystem nach erhöhten Konzentrationen von Glucose und Insulin

Zusammenfassung. An Rattenleberschnitten wurde mit einer Mikrosuperfusionstechnik, die eine dauernde Kontrolle des Perfusatflusses erlaubt, die Lipidsynthese aus ${ }^{14} \mathrm{C}$-Glueose und ${ }^{3} \mathrm{H}$-Alanin gemessen. Eine Erhöhung des Glucosesubstrats führte zu einer sofortigen Steigerung der Fettsäuresynthese. Zugegebenes Insulin erzeugte ebenfalls einen erhöhten ${ }^{14} \mathrm{C}$-Einbau in die Lipide. Beide Effekte waren unabhängig. - Diese beiden Faktoren können in der Hypertriglycerinämie nach hoher Kohlenhydrataufnahme oder beim Diabetes wirksam sein.

Key words: Lipid synthesis, liver slices, insulin, glucose concentration, superfusion system, diabetes.

\section{Introduction}

Recent advances in the study of lipid metabolism have revealed an intimate interrelationship with the metabolic pathways of carbohydrate utilisation. The hyperlipidaemia associated with some cases of uncontrolled diabetes is well known, as is the pathological state of carbohydrate induced lipaemia in man $[1,2]$. In normal volunteers the administration of an isocaloric diet containing $>7 \mathrm{~g} / \mathrm{kg}$ carbohydrate results in initial elevation of circulating triglycerides, and reduced clearance of an exogenous triglyceride load [3]. Some experiments suggest that the type of carbohydrate fed may further influence the degree of hyperlipaemia [4].

The circulating triglyceride at any given time is derived from two sources: the intestine and the liver. In the post-absorptive state the principle source of circulating triglyceride is the liver, where esterification of both circulating and de noro synthesised fatty acids is succeeded by coupling to a protein and excretion into the plasma, chiefly as very low-density lipoproteins (VLDL).

High circulating free fatty acid levels have been shown to be associated with increasing hepatic output of triglyceride [5], and this mechanism may contribute to the hypertriglyceridaemia associated with Cushing's disease [6]. The administration of a high carbohydrate diet would, however, be expected to reduce circulating free fatty acid levels, implying other mechanisms for the hyperlipaemia observed in this condition. These may include direct stimulation by the absorbed carbohydrate of hepatic lipid output, or its secondary increase by higher circulating insulin levels.

In the choice of an experimental system for the in vitro study of hepatic lipid synthesis, established experimental models have their limitations. Tissue slice experiments of classical design do not allow for the sequential study of the effect of hormone and substrate changes, while perfused whole liver experiments are by definition unsuitable for use with biopsy specimens.

We have investigated further [6a] the applicability of a continuously superfused rat liver slice system as an experimental model for the study of some factors relevant to diabetic and carbohydrate induced hyperlipaemia.

\section{Materials and Methods}

Krebs ringer bicarbonate was prepared according to the standard technique [7] but with $\mathrm{K}^{+}$and $\mathrm{Na}^{+}$ concentrations set at 70 and $53 \mathrm{mEq} /$ litre respectively [8]. Two percent $w / v$ recrystallised bovine serum albumin (Armour) was added and the $\mathrm{pH}$ checked to 
7.4. Uniformly labelled ${ }^{14} \mathrm{C}$-glucose or ${ }^{3} \mathrm{H}$-alanine (Radiochemical Centre, Amersham, Buckinghamshire) was added with unlabelled substrate to final concentrations of 1.25 to $80 \mathrm{mM}\left(1 \mu \mathrm{Ci}{ }^{14} \mathrm{C} / \mathrm{ml}\right)$ glucose and alanine $0.80 \mathrm{mM}(1.33 \mu \mathrm{Ci} / \mathrm{ml})$. Blood bank human plasma was separated from erythrocytes by gentle centrifugation at $4^{\circ}$ and diluted $1: 1$ with buffer to which glucose was added to a final concentration of $10 \mathrm{mM}$.

Male wistar rats of $150-200 \mathrm{~g}$ wt. fed ad lib on a standard laboratory diet, were stunned by a blow on the head, decapitated, and the livers immediately placed in ice cold $0.9 \%$ saline solution. Liver slices were prepared ( $0.4 \mathrm{~mm}$ thickness, approx. $200 \mathrm{mg}$ ) with a Stadie-Riggs microtome and washed in saline solution at $4^{\circ}$ before addition to the superfusion chamber [9]. The slow perfusion peristaltic pump delivered approximately $3 \mathrm{ml} / 15 \mathrm{~min}$ through the incubation chamber, from a $80 \mathrm{ml}$ reservoir maintained at $37^{\circ} \mathrm{C}$ and the superfusate was fraction. collected in graduated centrifuge tubes without recycling after an initial $20 \mathrm{~min}$ equilibration. Where relevant perfusate reservoirs were interchanged at mid-point in the experiment, and insulin addition made either by addition to the reservoir or by injection into a sidearm on the afferent circuit.

After collection the superfusate was extracted into five volumes Dole medium [10]. The heptane phase

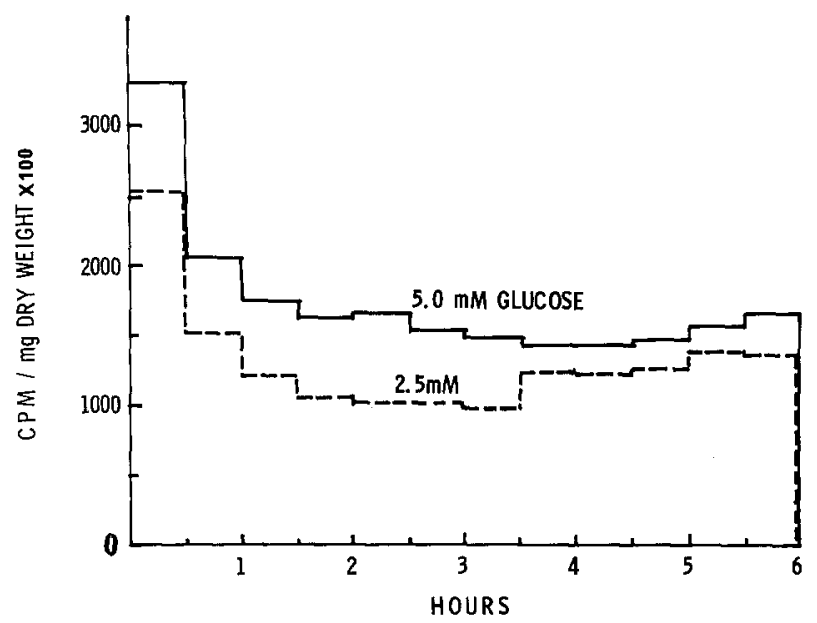

Fig. 1. Perifusion: Baseline incorporation of ${ }^{14} \mathrm{C}$-glucose into lipid. Liver slices were prepared as described in Methods, and incubated in superfusion chambers in modified Krebs-Ringer buffer medium with glucose $2.5 \mathrm{mM} \ldots$ and $5 \mathrm{mM}---(1 \mu \mathrm{C} / \mathrm{ml}$ ), (Means of two experiments)

was washed three times with 0.4 volumes $0.03 \mathrm{~N}$. sulphuric acid, aliquots dried under a steam of hot air and counted in toluene PPO-POPOP (containing $4 \mathrm{~g}$ 2.5 diphenoxazole and $0.4 \mathrm{~g} p$ Bis-(2-(5-phenyloxazolyl) benezene per litre of AR grade toluene) in a Packard scintillation counter (Model 3320). For separation into lipid fractions further aliquots were dried down under nitrogen and resuspended in $20 \mu \mathrm{l}$ chloroform for streaking and thin lay chromatography using hexane : diethyl ether : acetic acid : methanol (80:20: $2: 3$ ) on Eastman chromatogram sheets, $20 \mathrm{~cm} \mathrm{X}$ $20 \mathrm{~cm}$.

At the end of superfusion the liver slices were blotted, weighed and extracted in chloroform-methanol $(2: 1)$ [11]. After addition of 0.4 volumes of $0.05 \mathrm{M}$ $\mathrm{NaCl}$ and separation of the phases, the lower chloroform phase was washed three times and a liquots dried down for chromatographic fractionation as for the superfusate.

In the classical liver slice experiments, slices of liver $(500 \mathrm{mg})$ were incubated in identical experimental buffer $(3 \mathrm{ml})$ for $2 \mathrm{~h}$ in a shaker (30 cycles $/ \mathrm{min})$ at $37^{\circ}$ in an atmosphere of $95 \% \mathrm{O}_{2}, 5 \% \mathrm{CO}_{2}$. The slices were blotted, weighed and the medium and slices processed respectively as described above. Boiled liver slices did not show significant activity, and re-extraction of Folch-extracted liver slices yielded insignificant radioactivity.

\section{Results}

Superfused liver slices incorporate ${ }^{14} \mathrm{C}$-labelled glucose into lipid at a relatively constant rate after the first 30 min (Fig. 1), and this is maintained for up to $6 \mathrm{~h}$ in the absence of stimulating factors. Replacement

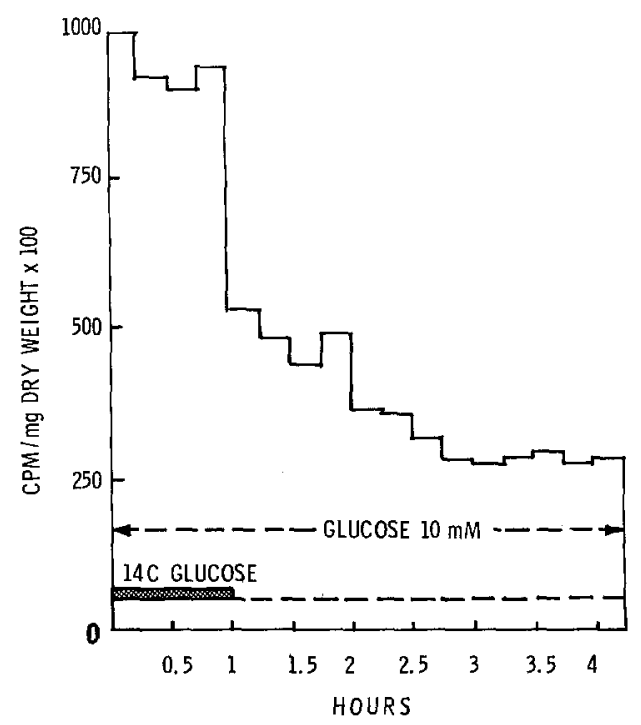

Fig. 2. Perifusion: ${ }^{14} \mathrm{C}$-labelling of perifusate lipid following equimolar substitution of ${ }^{14} \mathrm{C}$-glucose by non-radioactive glucose both at $10 \mathrm{mM}$ after the first hour. (Mean of two experiments)

of ${ }^{14} \mathrm{C}$-labelled substrate with equi-molar unlabelled glucose is followed by a rapid fall in lipid labelling (Fig. 2). Superfusion of the two adjacent incubation chambers containing liver slices from the same rat with buffers of differing glucose levels result in incorporation of ${ }^{14} \mathrm{C}$-labelled glucose into lipids in approximate proportion to the differences in substrate glucose concentration (Fig. 3). Exchange of buffer 
reservoirs between the two chambers after $2 \mathrm{~h}$, allowing $15 \mathrm{~min}$ for re-equilibration, resulted in rapid change in output of ${ }^{14} \mathrm{C}$-glucose-labelling between the two chambers, and in lipid output to a new steady-state of similar proportion to the differences in substrate concentration. In a later group of experiments, doubling

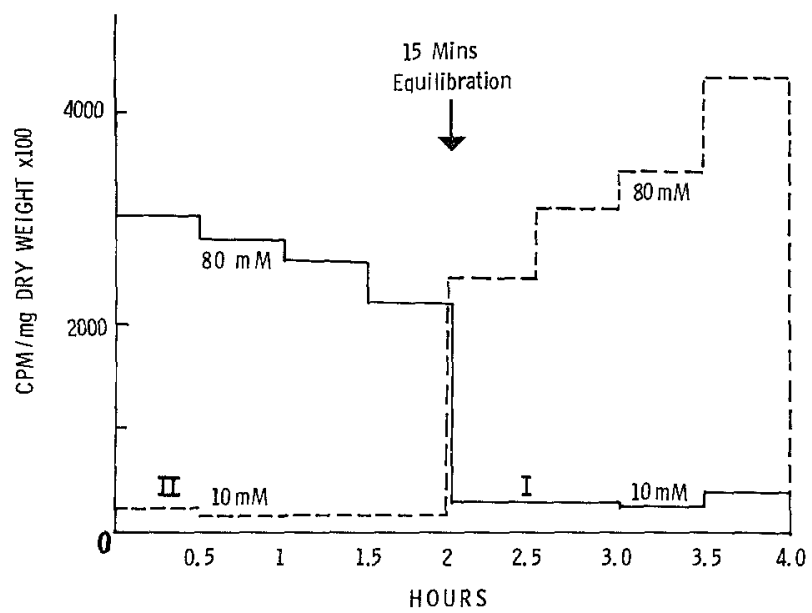

Fig. 3. Perifusion: Glucose ${ }^{14} \mathrm{C}$ incorporation into superfusate lipid following reservoir exchange between buffers of glucose levels : $10 \mathrm{mM}$ and $80 \mathrm{mM}$. (Two of a number of similar experiments). Perifusion chambers I _ _ and II ...

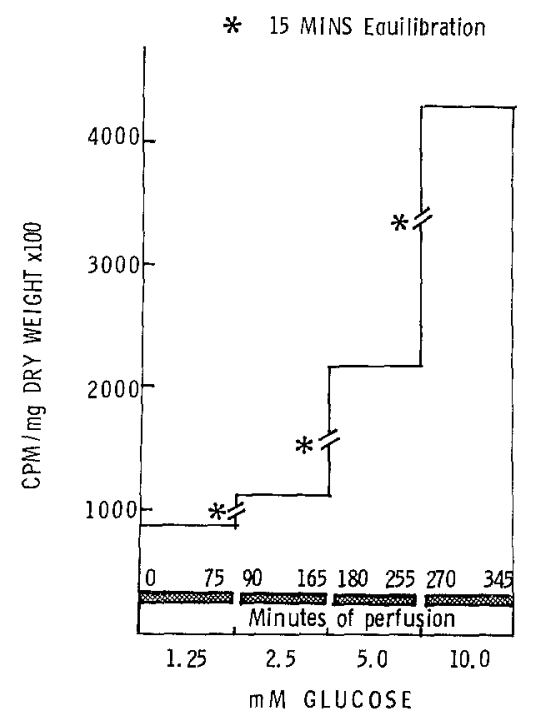

Further modification of the superfusate by the addition of human plasma (1:1 as defined in "Methods") produced a 12-fold increase in ${ }^{14} \mathrm{C}$-glucose incorporation into lipid (Fig. 6) and cross-superfusion after $3 \mathrm{~h}$ resulted in stimulation of the slices in the chamber receiving the plasma enriched superfusate, while $3 \mathrm{~h}$ superfusion with standard Krebs buffer did not result in return of the plasma-poor slices to the lower level of lipid synthesis.

In contrast to the relatively brisk arrival at new steady-state in lipid synthesis by liver slices superfused with medium of varying carbohydrate or plasma enrichment, the response to the addition of insulin is slower, and progressive over the $4 \mathrm{~h}$ following hormone injection (Fig. 7). Differing levels of glucose in the medium between the chambers containing slices from the same rat were reflected in proportionally differing basal values, but the difference is less apparent in the superfusate fractions following insulin addition. Insulin addition furthermore increased ${ }^{3} \mathrm{H}$-alanine incorporation into lipid under similar experimental conditions (Fig. 7b).

Thin layer fractionation of lipid extracts of tissue and superfusate reveal, however, a difference between the system under study and the more classical liver slice experiments. Whereas ${ }^{14} \mathrm{C}$.glucose carbon is incorporated principally into triglyceride and phospho.

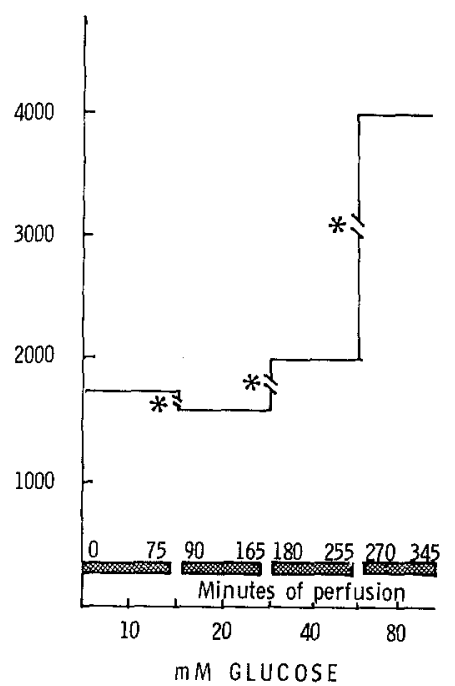

Fig. 4. Perifusion: The effect of sequential increase in superfusate glucose on ${ }^{14} \mathrm{C}$-incorporation into superfusate lipid (mean of four experiments); glucose concentrations $1.25,2.5,5.0$ and $10.0 \mathrm{mM}$, and in a second series of experiments $10,20,40$ and $80 \mathrm{mM}$

of substrate concentration was undertaken in pairs of chambers, allowing 15 min for equilibration between 75 min sampling periods (Fig. 4). Concentrations investigated ranged from 1.25 to $80 \mathrm{mM}$ and over this range the ${ }^{14} \mathrm{C}$-glucose incorporated by liver slices was increased with the increasing substrate glucose concentrations. These changes have been confirmed in the classical liver slice experiments (Fig. 5). lipid fractions of tissue extracts in both superfusion and classical type experiments, isotopic incorporation of superfusate extracts is principally into the free fatty acid fraction, with differences only resulting between the addition of glucose, insulin or half-strength plasma (Table 1). In similar designed experiments to those described, (Tulloch - unpublished data) the triglyceride/free fatty acid ratios were not altered by further 
addition of aminoacid mixture matching rat plasma composition, while palmitate addition above $1.0 \mathrm{mM}$ decreased the total ${ }^{14} \mathrm{C}$-glucose carbon incorporation into superfusate lipids. Other hormones, including ACTH $(200 \mathrm{mU} / \mathrm{ml})$, growth hormone $(1 \mu \mathrm{g} / \mathrm{ml})$,

\section{Discussion}

The superfusion system allows sequential sampling of the lipid output from small quantities of hepatic tissue such as would be obtained by operative biopsy
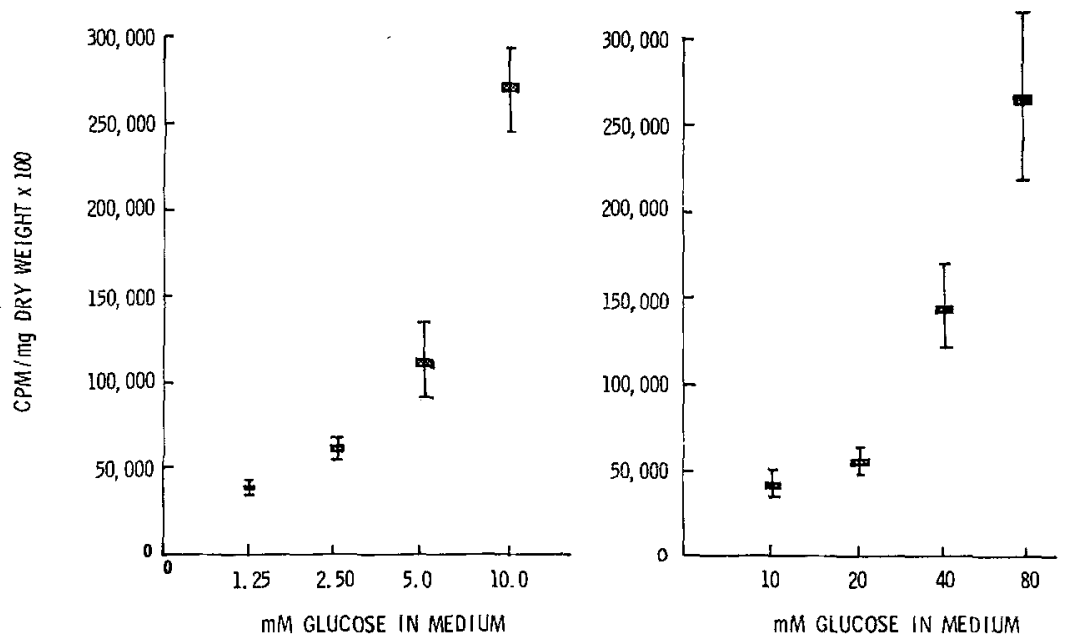

Fig. 5. Liver slices: The effect of increasing glucose concentration on substrate incorporation into lipid (each point mean of 20 experiments). Glucose concentrations $1.25,2.5,5.0$ and $10.0 \mathrm{mM}$, and in at second series of experiments $10,20,40$ and $80 \mathrm{mM}$

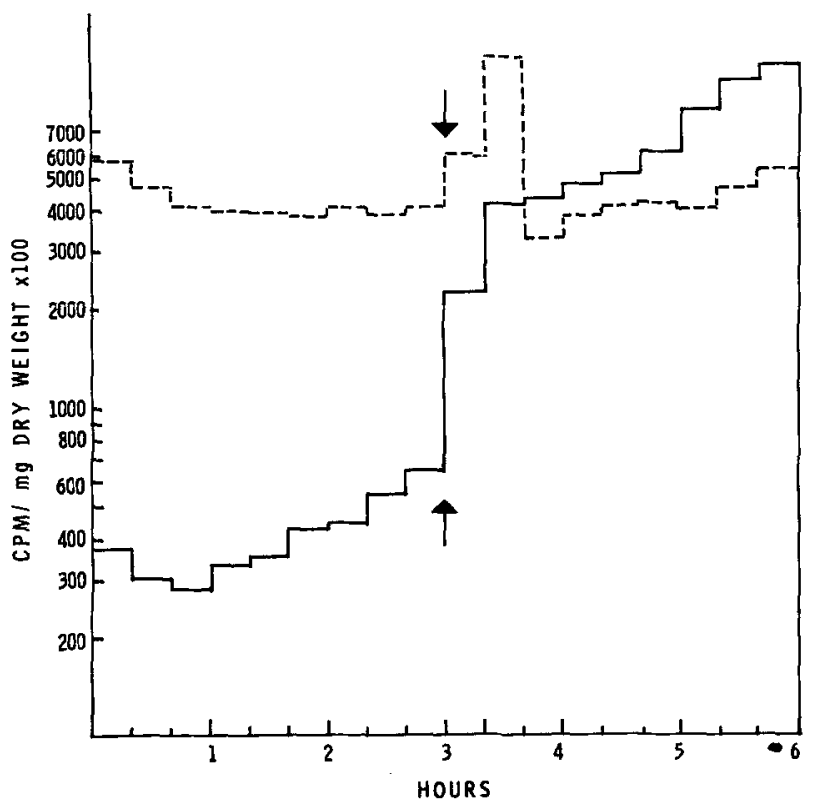

Fig. 6. Perifusion: The effect of half-strength human plasma on glucose incorporation into superfusate lipid (two typical experiments of four). At points indicated by arrows, chambers were cross-perifused and an equilibra. tion period allowed of $15 \mathrm{~min}$. Glucose concentration $10 \mathrm{mM}, 1.0 \mu \mathrm{C} / \mathrm{ml}$

adrenaline $(2-20 \mathrm{ng} / \mathrm{ml})$, noradrenaline $(10-100 \mathrm{ng}$ ) $\mathrm{ml})$, hydrocortisone $(20-\mathbf{2 0 0} \mu \mathrm{g} / \mathrm{ml})$ and triiodothyronine $(0.1-1.0 \mu \mathrm{g} / \mathrm{ml})$ were without discernible effect when added to the in vitro system at the concentrations indicated.

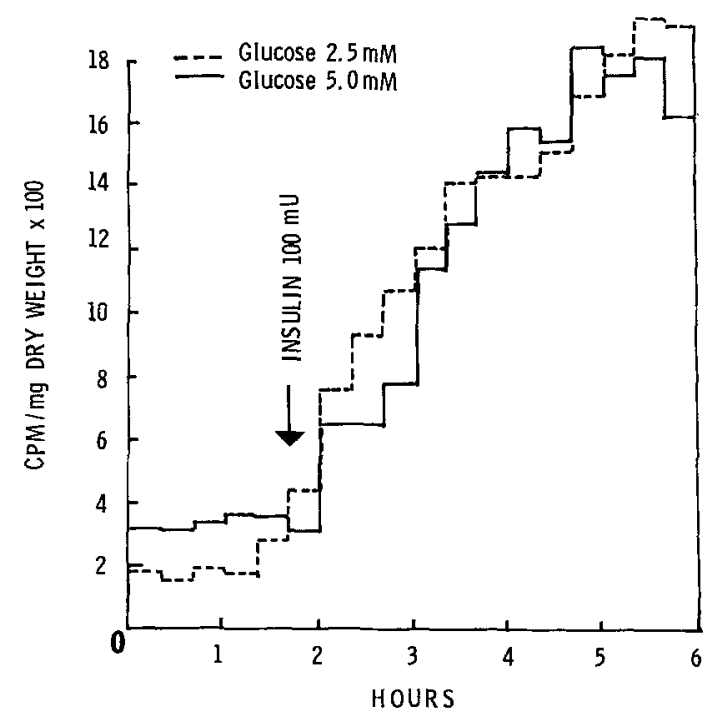

Fig. 7a. Perifusion: The effect of insulin addition on ${ }^{14} \mathrm{C}$-glucose incorporation into superfusate lipid (two of six experiments). Glucose concentration $2.5 \mathrm{mM}$... and $5.0 \mathrm{mM}-\ldots$ in Krebs bicarbonate buffer

(200-600 $\mathrm{mg}$ wet weight). Under sterile conditions a stable baseline of ${ }^{14} \mathrm{C}$-glucose incorporation into lipid persisted up to $6 \mathrm{~h}$, and response has been demonstrated to changes in the superfusion medium by increased de novo synthesis by the liver of free fatty acids.

The importance of hepatic de novo synthesis of plasma free fatty acid varies between the species. In man and rabbit, the principle source of plasma triglyceride fatty acid is circulating plasma free fatty acid 
$[2,5,12]$. In the rat, however, only a minor fraction of the free fatty acid originates from this pool, and quantitatively the most important source is hepatic lipogenesis [22]. In man under specific circumstances such as low fat, high carbohydrate diet, however, the

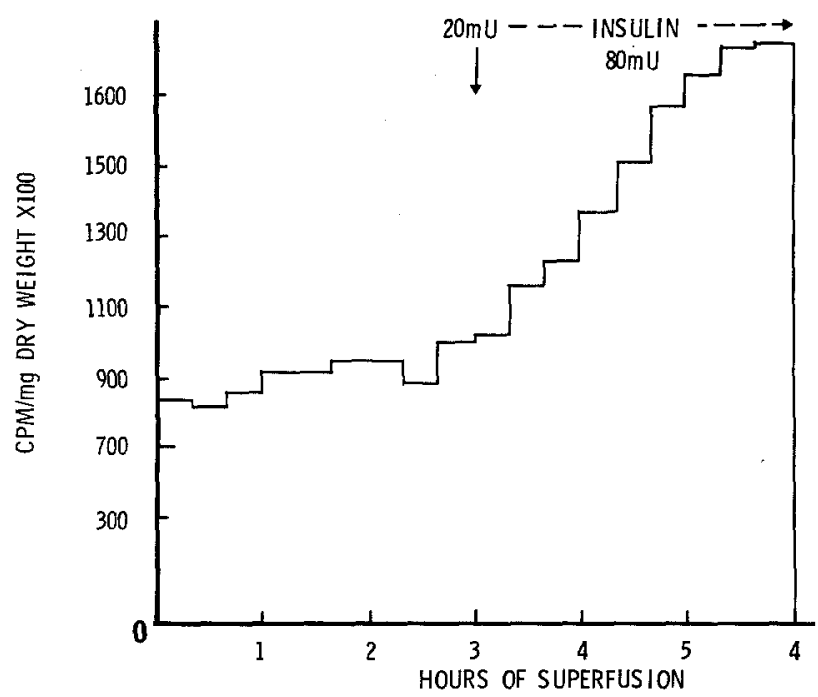

Fig. 7 b. Perifusion: The effect of insulin addition on incorporation of ${ }^{3} \mathrm{H}$-alanine into perifusate lipid (one of three experiments). Alanine $0.80 \mathrm{mM}, 1.33 \mu \mathrm{Ci} / \mathrm{ml}$ in modified Krebs bicarbonate buffer the portal circulation. The role of insulin in increased in vivo triglyceride synthesis remains contentious and it is of interest that whereas the stimulation of both glucose and alanine into lipid could readily be demonstrated using the liver slice perifusion system, such stimulation was not demonstrable using the classical liver slice incubation. Liver insulinase would be more effective in the classical liver slice procedure, which may explain both this difference in our findings with the two procedures, and why this insulin effect has been observed only by some other workers using high insulin doses in vivo and in vitro [14].

The lipid synthesis response in rat liver to increased glucose concentration is prompt and similar to that described for increased glycogen synthesis [15]. High carbohydrate feeding of rats has resulted in increased hepatic levels of pyruvate, acetyl CoA and malate [16] while these authors also noted that ${ }^{14} \mathrm{C}$ conversion from fructose to fatty acids further exceeded that from glucose, suggesting that fatty acid synthesing enzymes are unlikely to be the rate-limiting factor in glucose conversion. In both glucose and fructose-fed groups, hepatic CoA carboxylase levels were elevated, as were gluco- and fructokinase activity. The brisk response in lipid. synthesis in the experiments described here do not suggest de novo enzyme protein synthesis as a mechanism; but rather acceleration of an already active fatty acid synthesis, probably from

Table 1. Thin layer fractionation of perifusate and tissue slice extracts

\begin{tabular}{|c|c|c|c|c|}
\hline \multirow[t]{2}{*}{ Perifusate } & \multirow{2}{*}{$\begin{array}{l}\text { No. of } \\
\text { observ- } \\
\text { ations }\end{array}$} & \multicolumn{3}{|c|}{$\%$ of counts occurring as: } \\
\hline & & Phospholipid & Triglyceride & FFA \\
\hline Glucose $1.25 \mathrm{mM}$ & 12 & $6.2 \pm 0.61$ & $7.2 \pm 0.81$ & $86.9 \pm 3.52$ \\
\hline Glucose $2.5 \mathrm{mM}$ & 12 & $6.7 \pm 0.42$ & $10.6+1.20$ & $82.8 \div 6.30$ \\
\hline Glucose $\quad 5.0 \mathrm{mM}$ & 12 & $9.9+0.88$ & $10.0+3.21$ & $80.1+10.92$ \\
\hline Glucose $10.0 \mathrm{mM}$ & 12 & $8.2 \pm 1.23$ & $13.1 \pm 0.21$ & $75.1 \pm 15.38$ \\
\hline \multicolumn{5}{|l|}{ Half-strength plasma } \\
\hline $1-3 \mathrm{~h}$ & 9 & $23.7 \pm 2.88$ & $5.9 \pm 0.21$ & $70.4 \pm 5.31$ \\
\hline $3-6 \mathrm{~h}$ & 9 & $39.4 \pm 4.21$ & $7.8+0.42$ & $53.8+4.29$ \\
\hline Pre-insulin & 6 & $16.4 \pm 3.61$ & $8.3 \pm 1.51$ & $72.5 \pm 6.75$ \\
\hline Insulin $1 \mathrm{~h}$ & 6 & $28.3 \pm 4.92$ & $6.8 \pm 0.09$ & $64.8 \pm 5.68$ \\
\hline Insulin $2 \mathrm{~h}$ & 6 & $35.9 \pm 2.61$ & $6.2 \pm 0.94$ & $58.0 \pm 2.97$ \\
\hline Insulin $3 \mathrm{~h}$ & 6 & $22.3 \pm 1.75$ & $6.4 \pm 0.37$ & $71.0 \pm 4.29$ \\
\hline \multicolumn{5}{|l|}{ Tissue extracts of super- } \\
\hline fusion expts. & 12 & $18.7 \pm 0.92$ & $73.5 \pm 6.61$ & $7.8 \pm 1.23$ \\
\hline Liver slice lipids & 13 & $15.4 \pm 0.32$ & $80.3 \pm 4.37$ & $4.3 \pm 0.09$ \\
\hline
\end{tabular}

Slices and perifusate aliquots were extracted and concentrated as described in methods, and separated by thin layer chromatography as detailed using known standards.

importance of hepatic de novo free fatty acid synthesis is probably greater, since the principle increase in lipoproteins is the VLDL fraction and a similar situation may occur in cases of carbohydrate induced hyperlipaemia $[13,23]$. Should this be the case, then the findings reported here may well indicate a mechanism for the high levels of circulating triglyceride secondary to increased glucose concentrations within the increased glucose entering the hepatocyte, for it is permeable to glucose and has an active low-affinity glucokinase. Half-strength plasma addition to the perifusate similarly caused a brisk rise in FFA synthesis from glucose, and this persisted up to $3 \mathrm{~h}$ after crosssuperfusion with Krebs buffer.

By contrast, the response obtained following insulin addition without change in glucose concentration, 
was slower but progressive over the duration of the study. The site of insulin action is unknown, but it probably involves facilitating either glucose entry into cells, or its early intermediate metabolism. In the very permeable liver cell insulin effect may fall at one or more early points in glucose utilisation - e.g. phosphofructokinase, reduced levels of which have been reported in human diabetic adipose tissue [17]. However these effects in the hepatocyte must not only provide more substrate but also accelerate fatty acid synthesis in other ways, for we have seen it induces increased incorporation of ${ }^{3} \mathrm{H}$-alanine from the perifusate, and ${ }^{14} \mathrm{C}$ incorporation from aminoacids into fatty acid carbon is reduced in perfused livers from acute and chronic alloxan diabetic rats [24].

The significance of the above effects in the clinical situation of diabetic and nutritional hypertriglyceridaemia is difficult to assess. Although insulin in high dose affects in vivo lipid synthesis in rats [14], and some workers have reported elevated glucose and insulin levels in idiopathic hypertriglyceridaemia [18], some normal levels [19], and some decreased levels have also been described $[13,20]$. In the latter situation, decreased triglyceride clearance by peripheral tissues may be an important factor, since both adipose tissue lipoprotein lipase and intracellular alpha-glycerophosphate levels (for re-esterification) would provide insulin dependent factors for limiting triglyceride removal from the circulation.

The remaining differences between classical in vitro liver slice techniques and the superfusion system is the consistent incorporation of labelled precursor mainly into free fatty acid by the superfused slice. Since the major lipid output of the liver physiologically is triglyceride linked with apoprotein in very low density lipoproteins, component precursors were added both in the form of aminoacid mixtures approximating to rat plasma components, and also half-strength human plasma (Fig. 6 \& Table 1). Neither, however, was able to alter the free fatty acids to triglyceride ratio of the superfusate radioactivity although insulin and plasma increased the percentage of counts present as phospho-lipid, which could include phosphatidic acid. That an absence of cofactor or apoprotein acceptor remains the most likely reason for this deficit is further substantiated by the studies of Kook \& Rubenstein [21] on increased rat liver slice output of phospholipid in media of various lipoprotein constituents.

Acknowledament. The study was supported by a Medical Research Council Project Grant and a Clinical Research Fellowship to B.R.T. We wish to thank our colleagues Drs. J. Letarte, B. Lewis and D. Gompertz for help and encouragement.

\section{References}

1. Ahrens, E.H., Spritz, M.: Further studies on fat and carbohydrate induced lipaemia in man. Reduction of lipaemia by feeding fat. Biochemical Problems of
Lipids. Vol. 1, p. 304. New York: Frazier, A.C. Elsevier 1963.

2. Friedberg, S. J., Klein, R.F., Trout, D.L., Bogdanoff, M.D., Estes, E.H. : Incorporation of free fatty acids into plasma triglycerides in man. J. clin. Invest. 40, $1846-1848$ (1961).

3. Lewis, B., Mattock, M., Maervart, I. (unpublished data).

4. McDonald, I.; Effects of dietary carbohydrates on serum lipids in a 5-day regimen. Clin. Sci. 29, $193-198$ (1965),

5. Havel, R.J.: Conversion of plasma FFA into triglycerides of plasma lipoprotein fractions in man. Metabolism 10, 1031-1036 (1961).

6. Tulloch, B.R., Lewis, B., Fraser, T.R.: Hypertriglyceridaemia associated with Cushing's disease and the effect of pituitary ablation (in preparation).

6 A Letarte, J., Fraser, T.R.: Stimulation by insulin of the incorporation of $\mathrm{U}^{14} \mathrm{C}$-glucose into lipids released by the liver. Diabetologia 5, 358-359 (1969).

7. Umbreit, W., Burris, R., Stauffer, J.: Manometric techniques, p. 132. Minneapolis: Burgess 1964.

8. Abouna, G.M.: Pig liver perfusion: the effect of preparing and flushing the liver with various balanced solutions on its subsequent viability and function. Brit. J. Surg. 55, $761-768$ (1968).

9. Junod, A., Letarte, J., Lambert, A., Stauffacher, W.: Studies in spiny mice (acomys cahirinus): metabolic state and pancreatic insulin release in vitro. Horm. Metab. Res. 1, 45-52 (1969).

10. Dole, V.P.: A relation between NEFA in plasma and the metabolism of glucose. J. clin. Invest. 35, 150$154(1956)$.

11. Folch, J., Lees, M., Sloane Stanley, S.G.: A simple method for the isolation and purification of total lipids from animal tissue. J. biol. Chem. 226, $497-509$ (1957).

12. Eaton, R.P., Berman, M., Steinberg, D.: Kinetic studies of plasma free fatty acids and triglyceride metabolism in man. J. clin. Invest. 48, 1387-1396 (1969).

13. Fredrickson, D.S., Levy, R.S., Lees, R.S.: Fat transport in lipoproteins: an integrated approach to mechanisms and disorders. New Engl. J. Med. 276, 1970 III 32, 94, 148, 215, 273

14. Vester, J.W., Reino, M.L.: Hepatic glucokinase: a direct effect of insulin. Science 142, $590-593$ (1963).

15. Buschazzio, H., Exton, J.H., Park, C.: Effect of glucose on glycogen synthetase, phosphorylase and glycogen deposition in perfused rat liver. Proc. nat. Acad. Sci. 65, 383-389 (1970).

16. Zakim, D., Perdini, R., Herman, H., Sauberlich, H.: Mechanism for differential effects of high carbohydrate diets on lipogenesis in rat liver. Biochim. biophys. Acta 144, 142-149 (1967).

17. Galton, D.J., Wilson, J.P.D.: Glycolytic enzymes in adipose tissue of adult diabetics. Brit. med. J. $444-445(1970)$.

18. Reaven, G., Leaver, R., Stern, M., Farquhar, R.: Role of insulin in endogenous hypertriglyceridaemia. $\mathrm{J}$. clin. Invest. 46, 1756-1767 (1967).

19. Kane, P.J., Longcope, C., Pavlatos, F., Grodsky, G.: Studies of carbohydrate metabolism in idiopathic hypertriglyceridaemia. Metabolism 15, 471-486 (1965).

20. Havel, R.J.: Plasma lipoproteins. Adv, intern. Med. 15, $117-146$ (1969).

21. Kook, A.I., Rubenstein, D.: The role of serum lipoproteins in the release of phospholipids by rat liver slices. Biochim. biophys. Acta 202, 396-398 (1970).

22. Nikkila, E.: Control of plasma and liver triglyceride 
kinetics by carbohydrate metabolism and by insulin. Adv. Lipid Res. 9, 63-132 (1970).

23. Ruderman, N., Jones, A., Krauss, R., Shafrir, E.J.: A biochemical and morphological study of VLDL in carbohydrate induced hypertriglyceridaemia. J. clin. Invest. 50, 355-367 (1971).

24. Wilcox, H., Dishman, G., Heinberg, M.: Hepatic lipid metabolism in experimental diabetes, IV. In- corporation of amino acid ${ }^{14} \mathrm{C}$ into lipoprotein, protein and triglyceride. J. biol. Chem. 243, 666-675 (1968).

Dr. B.R. Tulloch

Endocrine Unit

Dept. of Medicine

Royal Postgraduate Modical School

London W. 12/England 